\author{
INVITED PRESENTATION \\ FRESNO STATE UNIVERSITY \\ 75TH ANNIVERSARY OF THE UNIVERSITY
}

\title{
VOLCANIC HAZARDS: PERSPECTIVES FROM ERUPTION PREDICTION TO RISK ASSESSMENT FOR DISPOSAL OF RADIOACTIVE WASTE
}

\author{
BRUCE CROWE \\ LOS ALAMOS NATIONAL LABORATORY
}

\section{SUMMARY OF PRESENTATION}

More and more frequently, geologists are being asked by the public to make specific predictions on the future activity of geologic phenomena. These predictions often meet with mixed success. Three examples are described that illustrate interactions between geologists and the public: two involve volcanic eruptions; the third is concerned with disposal of high-level radioactive waste. La Soufriere Volcano on the island of Guadeloupe in the Caribbean, showed renewed earthquake activity in mid-1975 (100 earthquakes/month) and this activity peaked in mid-1976 (> 1000 earthquakes/month) accompanied by numerous phreatic eruptions. Fresh glass was incorrectly identified in the phreatic eruption clouds suggesting the presence of new magma. Newly sited tilt meter stations recorded extremely high rates of tilt suggesting rapid inflation of the volcanic edifice by injection of subsurface magma. These tilt rates were later shown to be in error. The combination of evidence for new magma and political pressures from island inhabitants and the world press led French volcanologists to recommend to civil authorities that the south end of the island be evacuated. More than 70,000 people were evacuated for 110 days. Earthquake and volcanic activity gradually diminished through late 1976 and all activity ceased by March 1977 . Mount St. Helens Volcano in southern Washington entered a phase of renewed activity in March of 1980 that was remarkably similar to the activity of La Soufriere Volcano. The volcano showed an increase in seismic activity accompanied in late March and April by episodic phreatic ash emissions. Initial studies revealed virtually no tilt at the base of the volcano. Subsequent studies show that the upper north face of the volcano was 
deforming horizontally at a peak rate of 2 meters/day. Access was closed and residents were evacuated from the surrounding areas of the volcano, to the dismay of the public and logging iterests. This closure and evacuation was ordered by officials of the State of Washington based on hazard zone predictions by the U.S. Geological Survey. Mt. St. Helens erupted at 0832 PDT on May 18. There were no precursory changes in seismic activity or deformation preceding the eruption. Volcanic hazard investigations are being conducted for the Nevada Nuclear Project Waste Storage Investigations/, a program concerned with storage of high-level radioactive waste at a site in southern Nevada. Five Quaternary volcanic centers are present within a range of 8 to $20 \mathrm{~km}$ of the exploration block at Yucca Mountain. Yucca Mountain is located in a broad zone of volcanic activity, the Death Valley-Pancake Range volcanic zone. Probability estimates of the likelihood of the combined occurrence of a future volcanic event and the likelihood that the volcanic event will intersect a buried repository at Yucca Mountain are very low $-10^{-8}$ to $10^{-10}$ per year. The radiological consequences of penetration of a repository by basaltic magma followed by eruption of the magma at the surface are limited. This combination (low probability and limited consequences) indicate ${ }^{5}$ the risk of volcanism at the Yucca Mountain is low. This interpretation has generally been favorably reviewed although detailed criteria for review have not been established. Studies are continuing to explore aeromagnetic anomalies that may be buried basaltic centers. These sites will be drilled and samples studied to fully characterize the past geologic record for calculations of rates of volcanic activity. Efforts to determine the age of the youngest volcanic center in the Yucca Mountain region have proven problematic. The unlikely but possible occurrence of hydrovolcanic eruptions (water-magma explosions) could change evaluations of the consequences of an eruption.

\title{
DISCLAIMER
}

\begin{abstract}
This report was prepared as an account of work sponsored by an agency of the United States Government. Neither the United States Government nor any agency thereof, nor any of their employees, makes any warranty, express or implied, or assumes any legal liability or responsibility for the accuracy, completeness, or usefulness of any information, apparatus, product, or process disclosed, or represents that its use would not infringe privately owned rights. Reference herein to any specific commercial product, process, or service by trade name, trademark, manufacturer, or otherwise does not necessarily constitute or imply its endorsement, recommendation, or favoring by the United States Government or any agency thereof. The views and opinions of authors expressed herein do not necessarily state or reflect those of the United States Government or any agency thereof.
\end{abstract}




\section{DISCLAIMER}

Portions of this document may be illegible in electronic image products. Images are produced from the best available original document. 